\begin{tabular}{|c|c|c|c|c|c|c|}
\hline \multirow{4}{*}{ Impact Factor: } & ISRA (India) & $=3.117$ & SIS (USA) & $=0.912$ & ICV (Poland) & $=6.630$ \\
\hline & ISI (Dubai, UAE & $=0.829$ & РИНЦ (Russia & $=0.156$ & PIF (India) & $=1.940$ \\
\hline & GIF (Australia) & $=0.564$ & ESJI (KZ) & $=8.716$ & IBI (India) & $=4.260$ \\
\hline & JIF & $=1.500$ & SJIF (Morocco & $=5.667$ & OAJI (USA) & $=0.350$ \\
\hline
\end{tabular}

\section{SOI: 1.1/TAS DOI: 10.15863/TAS International Scientific Journal Theoretical \& Applied Science}

p-ISSN: 2308-4944 (print) e-ISSN: 2409-0085 (online)

Year: 2019 Issue: $04 \quad$ Volume: 72

Published: 30.04.2019 http://T-Science.org
QR - Issue

QR - Article
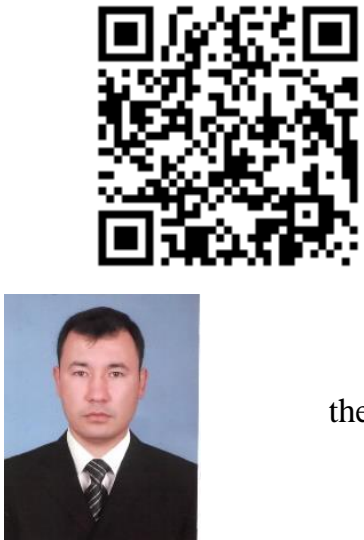

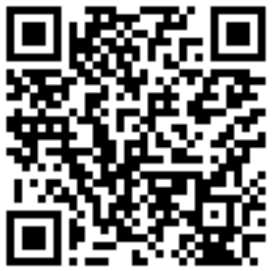

Dilshod Khudoyberdiyev a teacher,

the department of social science,

Karshi State university

\title{
THE FACTORS SERVING TO FORM PERSONAL CONSUMPTIVE CONDUCT
}

Abstract: In this article the notion of "consumptive conduct" is defined. In author's opinion, the consumptive conduct is considered to be complex actions, adapted under the natural and social conditions in order to meet the needs of a consumer in products and services and realizing his or her desires in consumption.

The conduct of consumerism in an individual is formed under the influences of different factors. The author analyzes the impact of cultural, social, personal and psychological factors on the consumptive conduct of an individual.

Key words: consumption, behavior, consumptive behavior, peculiarities of consuming behavior, the factors, shaping consuming behavior, cultural factors, social factors, personal factors, spiritual factors, smart consumer behavior.

Language: English

Citation: Khudoyberdiyev, D. (2019). The factors serving to form personal consumptive conduct. ISJ Theoretical \& Applied Science, 04 (72), 489-492.

Soi: http://s-o-i.org/1.1/TAS-04-72-62 Doi: crossef https://dx.doi.org/10.15863/TAS.2019.04.72.62

\section{Introduction}

In the current century, changing people's needs and desires has radically influenced their consuming habits. The contemporary person is turning into an individual one, who dives into flow of the consumption, i.e. "consuming person". To make a conclusion on the basis of the views of specialists, who analyzed the subject from economic [1], sociologic [2], social-psychological [3] point: of course, this tendency is included in the content of social-philosophical issues of which should be investigated deeply. However, before undertaking this task, it is important to define the concept of "consumption behavior" and the factors that can influence its formation. In order to define the category of "consumer behavior", it is crucial to pay special attention to the two concept definitions at first. First of all, it is impossible to express the specific peculiarities of consumption behavior without revealing the essence of the definition "behavior". Secondly, the word "consumption" denotes the field of belongingness- this respect of the issue must be on the central point of attention. Behavior is the combination of human efforts to adapt and adjust to natural and social conditions. Regularly the behavior of the human being refers to their activity. Actually, it isn't so. When a person's behavior is manifested in the pursuit of adaptation to reality and his activity is based on the actions, aimed at changing this reality. Human behavior has its classification. We do not dwell on this classification as it doesn't belong to the research object. Only the following should be stated that one of its main features includes efforts, that is connected with consumption of various products and services.

\section{Materials and Methods}

Consumption is the main source of meeting human requirements. As long as the system of requirements exist, there's also consumption. The requirement causes the necessity of consuming various products and services, so that a human being should adapt to existing social conditions and that one should be compatible with the norms and principles in society with objective conditions and subjective factors. Thus, the certain type of behavior in consumption - consumptive behavior become apparent.

Consumptive behavior is deduced from the meeting the requirements of the consumers for various products and services and the combination of the efforts, made by the consumer to meet the natural and 


\begin{tabular}{|c|c|c|c|c|c|c|}
\hline \multirow{4}{*}{ Impact Factor: } & ISRA (India) & $=3.117$ & SIS (USA) & $=0.912$ & ICV (Poland) & $=6.630$ \\
\hline & ISI (Dubai, UAE & $=0.829$ & РИНЦ (Russia & $=0.156$ & PIF (India) & $=1.940$ \\
\hline & GIF (Australia) & $=0.564$ & ESJI (KZ) & $=8.716$ & IBI (India) & $=4.260$ \\
\hline & JIF & $=1.500$ & SJIF (Morocco & $=\mathbf{5 . 6 6 7}$ & OAJI (USA) & $=0.350$ \\
\hline
\end{tabular}

social conditions, taking into account the likelihood of their consumption.

Like other patterns of behavior, consumptive conduct has a number of specific features, which allow you to deeply understand the essence and content laws of its formation and development of consumer behavior. In our opinion these features are the followings:

- Consumptive conduct has a concretehistorical feature; it hasn't the same unique and constant reputation for all ages; As social conditions, the factors and tools, that influence on consumers are changing, purpose and objectives of consuming behavior has changed;

- at the certain time not only one type of consumptive behavior, but also various models that are proportionate to community hierarchy, demographic state, classroom structure and cultural level dominate; the following models are composed of common and specific elements;

- Consumptive behavior has changeable, still or stable and unstable characteristics; As the need for any product appears, the efforts, which meet this requirement comes into existence, eliminating the demand leads the loss of the effort;

- Consumptive conduct consists of synthesis of rationality and perceptive elements; in most cases it is focused on satisfying the emotional needs of consumers;

- In the content of consumptive conduct, owning artifacts, which has turned into public consuming product and also admitted as a custom is of great importance;

- Consumptive behavior develops in free state of principles of inheritance, because there isn't mechanism of transferring consuming tradition from generation to generation; the system of the needs and desires which is part of its structure is indispensable and actual only at a certain period, after that new requirements and desires appear instead of it.

- Although elements of consumptive behavior satisfies consumers' daily and lively needs and desires, it doesn't affect its mental progress, that is personal belief, qualities and features, citizen and life position are not developed.

As we have already stated consumer behavior has a variable character. Naturally, these changes are not considered indirect processes. There are encouraging factors to it. In general, there is no single theoretical approach to the factors which influence on modifying and forming of the consuming behavior in scientific sources of consuming behavior. According to the object of the study, the researchers distinguish a set of the factors from each other. Among them, the classification of factors suggested by professor F.Cottler, in school of Management at Northwestern university plays indispensable role.

According to the scientists, consumer decision about the choice of this or that product, service doesn't happen indirectly. Any shopping is carried out under the influence of many cultural, social, personal and psychological factors.

The factors, which influence of this personal consuming behavior efficiently can be shown separately on the basis of this negotiation.

1.Culture is one of the most controversial reasons for determining the specific dimensions of human needs and behavior. The person firstly acquired his /her family then the material and cultural values, dreams and desires, attempts and efforts of the society, which those belong to the requirement for the discrepant product and services is formed according to the system of the system of these traditions, hope and desire. F. Cottler presents this relationship as the example of Betty Smith. Betty adores photocamera. This willing is the result of that she has been brought up in modern society, where photocamera and phototechnics are appreciated. While there may be no value and requirement for photocamera for the members of the tribe, who are living in some place of Australia, as they are not interested in and free of scientific-technical development of the age.

As it is known, any culture is composed of various components, that is subculture. Subculture creates finding the people who are like to themselves, communicating with them, the suitable possibilities. The culture of small group, class relating to the person influences national and rational belongings, religious belief, the system of traditions and like these its requirement influence on the complex of requirement and consumers' rights seriously.

A human being selects nutritional products, outfits, the forms of having rest, even profession and life destination are chosen under the influence of this subculture. One product may be valuable for some members of the culture, but it can be invaluable for the representative of other subculture. That's why there is the certain dissimilarity between people's consuming behavior according to the groups.

2. Forming consumptive behavior is conducted under the influence of different social factors. The type of these factors may cover referent groups of person, social life in their family, social slogan, social roles under people's responsibility...

According to the Philip Cottler, the referent group refers to a group of capable of directly influencing the consciousness and activity of a person.

Usually family, neighbors and colleagues are considered such group. Informal groups that are based on different interests can also be regarded as referent groups. Individual's lives and activities in society is a part of the same group. This group influences the human being in three ways: first he introduces the person to the new norms of behavior; Second it promotes the idea of individual; thirdly it adapts to the consumption of products and services that are acceptable to the group. The higher the 


\begin{tabular}{|c|c|c|c|c|c|c|}
\hline \multirow{4}{*}{ Impact Factor: } & ISRA (India) & $=3.117$ & SIS (USA) & $=0.912$ & ICV (Poland) & $=6.630$ \\
\hline & ISI (Dubai, UAE & $=0.829$ & РИНЦ (Russia) & $=0.156$ & PIF (India) & $=1.940$ \\
\hline & GIF (Australia) & $=0.564$ & ESJI (KZ) & $=8.716$ & IBI (India) & $=4.260$ \\
\hline & JIF & $=1.500$ & SJIF (Morocco & $=5.667$ & OAJI (USA) & $=0.350$ \\
\hline
\end{tabular}

authority of the referent group, the greater will be its impact on the consumer behavior.

The social status of the family and family traditions, especially the steps of family life have strong impact on the change in consumptive behavior. Actually a young man or a girl, who accommodate with their parents , a newly-married couple, a husband and wife with their offspring, a father and mother who are busy with bringing up teenagers, an elderly person who continues to work, a retirement age an old woman and man- their shopping habits radically differ from each other.

The social state and social activity of human influences to consumptive conduct. As you know people are forced to play a variety of roles as members of different social groups. For instance, he or she is as the relative of a parent, i.e. husband or wife, and a livelier of his or her own business. All of these roles require the person to carry out the certain efforts. Each of these roles has a strong impact on its consumer behavior, as well as consumers.

Moreover, each role requires to have its own social status. For example, the person's status is higher than being a child. This position, the role of the company demands to use the products and services that are appropriate to the company.

According to American experts, the company's presidents spend their valuable time in Mercedes or Cadillac, and they buy expensive costumes, drink, Katti Sark whiskey. It should be noted that these symbols, which indicate the person's social status may have different appearance in different regions. For example, in New York these symbols include fishery and cosmetic operations for men, while Chicago has the tradition of purchasing only the products which are listed in catalogues, night parties and caviar refers to Houston and the outfits produced by Izod belong to San Francisco.

Individual factors are one of the most crucial factors of consumptive conduct. They include the age, profession, career, lifestyle, thoughts and so on. However as the younger generation grows, the structure services and services that consumers use during their daily lives change radically. Consumption of food also differs at different stages of life. Dressing habits, household appliances, rest types, thoughts and taste are changeable.

The branch will have certain impact on the nature of the goods and services purchased by its occupation. The worker finds appropriate not only consuming the necessary products for his or her professional activity but also the dainties, which are considered valuable in this area. But the head of the company focuses on the entire new complex of products hugely: he selects the best of services, the suits that represents his status. Marketing services of developed countries doesn't distract this feature of consuming process, thus in recent years markets, grocery stores, which are designed for certain profession have been expanded for certain professions and social statuses.

The economical state of the person is especially crucial in the content of personal factors which influence consumption behavior. It is known to us that the economical state of the person is marked with his or her income, the amount of deposits, the ownership of property and etc. on the one hand these factors determine the shopping capability of the person. on the other hand, it shows the quality and norms of the products and services, which he or she tends to purchase. The person of whom the economical state is stable as a consumer's essentially different from that of a person in an unstable economic situation.

There is another aspect of the issue. In certain cases, two people, those are representatives of the same subculture, in the same economic position and who are responsible for similar roles may be sharply differentiated according to the efforts as consumers. For example, the people, who are carrying out in honorable positions of those the one may be hedonist and the second one may be ascetic. Consequently, a set of personal factors that can influence the formation of consumer behavior should include a lifestyle of personality. Philip Cottler also considers personal traits (determination, willingness, self-esteem, enthusiasm, cautiousness, discipline, flexibility and etc.) and self-imagination about the person, as the personal factors which can influence consuming behavior. According to his opinion, the certain trait claims to select this or that product. For instance, the people who tend to converse with people like to consume beer.

4. The Person's choice as a consumer also influences spiritual factors. Among them people's wish is of particular importance. We have emphasized that the source of humans' efforts as consumer is their needs. However, naturally any requirement cannot be hit to buy this or that product. As you know, types of personal requirement depends on physiological and spiritual necessity. Most of them do not claim the source of effort. As they don't have actual and intensive importance may turn into personal willing. The very willing forms consumptive behavior in other words encourage purchasing the products and services. However, after getting the product, the desire to achieve the things fades, its place is replaced by another dwelling.

The person's intelligence affects on consumers' manner, human beings' intelligence which is related to the consumption has its peculiarity. For instance, the one who wants to buy any kind of production came to the market. Firstly, he or she only realized the product that he wants to purchase. For example, the consumer who decided to buy a camera one may not see other technical Gadgets that are placed beside him or her.

One of the spiritual factors that highly influence on consumptive conduct is related to belief. Strong 


\begin{tabular}{|c|c|c|c|c|c|c|}
\hline \multirow{4}{*}{ Impact Factor: } & ISRA (India) & $=3.117$ & SIS (USA) & $=0.912$ & ICV (Poland) & $=6.630$ \\
\hline & ISI (Dubai, UAE & $=0.829$ & РИНЦ (Russia & $=0.156$ & PIF (India) & $=1.940$ \\
\hline & GIF (Australia) & $=0.564$ & ESJI (KZ) & $=8.716$ & IBI (India) & $=4.260$ \\
\hline & JIF & $=1.500$ & SJIF (Morocco & $=\mathbf{5 . 6 6 7}$ & OAJI (USA) & $=0.350$ \\
\hline
\end{tabular}

belief defines the circle of products and services that an individual person might consume. For example, a person who is strongly addicted to Islam, restrain himself from receiving the services and consuming the products such as pork and alcoholic drinks that Islamic religion puts prohibition. We can witness the advice and measures concerning to consuming in another religious dogmas. But this factor which influences on personal consumption behavior is not dependent on only religion. Beliefs, created on a foundation of scientific and religious knowledge, customs, traditions and imaginations and hopes could be such a source.

\section{Conclusion}

Finally, one of the last spiritual factor that affects consumer's behavior is personal attitude. Personal attitude is based on the system of person's certain knowledge and positive or negative attitude to the object. This marking system can serve as a logical basement for opting the types of products, intended for consumption. For instance, the person who has a positive attitude to the economy and culture of Japan and inhabitants' living condition is likely to consume the products or goods that have been produced in the very country. Contrarily, the person, who has a negative deduction doesn't find normal the consumption of the country's production appropriate.

Obviously, consumption behavior is formed under the influence of different factors. It should be noted that, as the social and historical conditions change, some of them may be of priority importance, while others lose their reputation. The scientific concepts about these factors create the possibility not only to query the rules of consumer behavior, but also to investigate it sensibly.

\section{References:}

1. Cotler, F. (2007). Osnovi marketinga. Cratkiy kurs. Moscow: Vilyame.

2. (1981, September 21). Flaunting Wealth: It's Back in Style. US News \& World Report. pp. 6164.

3. Marks, K., \& Engel's F. (1983). Kapital. Tom I. Sochineniya. 2-e izd. Moscow: Politizdat.

4. Smit, A. (2017). Issledovanie o prirode $i$ prichinakh bogatstva narodov. Moscow: Eksmo.

5. Samuel'son, P., \& Nordkhaus, D. (2015). Ekonomika. Moscow: Vil'yame.

6. Fisher, I. (2001). Pokupatel'naya sila deneg. Moscow: Delo.

7. Fridman, M. (1996). Kolichestvennaya teoriya deneg. Moscow: Delo.
8. Zimmel', G. (1996). Sotsial'naya differentsiatsiya. Izbrannoe. Tom 2. (pp.301465). Moscow: Yurist.

9. Veblen, T. (1984). Teoriya prazdnogo klassa. Moscow:Progress.

10. Bodriyar Zh. (1995) Sistema veshchey. Moscow: Rudomino.

11. Gelbreyt Dzh. (2004). Novoe industrial'noe obshchestvo. Moscow: AST.

12. Freyd, Z. (1990). Psikhologiya bessoznatel'nogo. Moscow: Prosveshchenie.

13. Maslou, A. (1999). Motivatsiya i lichnost'. SPb.: Evraziya. 